\title{
A Study of Displacement in Jean Rhys' Novel Wide Sargasso Sea
}

\author{
Inna Malissa bte Che Jamal (Corresponding author) \\ Department of English \\ Faculty of Modern Languages and Communication \\ Universiti Putra Malaysia, 43400, Serdang \\ E-mail: lissajamal@yahoo.com \\ Hardev Kaur A/P Jujar Singh \\ Department of English \\ Faculty of Modern Languages and Communication \\ Universiti Putra Malaysia, 43400, Serdang \\ E-mail: jshardev@yahoo.com \\ Manimangai Mani \\ Department of English \\ Faculty of Modern Languages and Communication \\ Universiti Putra Malaysia, 43400, Serdang \\ E-mail: manimanggai@yahoo.com
}

Doi:10.7575/aiac.alls.v.5n.5p.111

Received: 08/07/2014

URL: http://dx.doi.org/10.7575/aiac.alls.v.5n.5p.111

Accepted: 30/08/2014

\begin{abstract}
Wide Sargasso Sea, by Jean Rhys, is a novel filled with tragedy; two characters in conflict meet in circumstances not in their best interests but rather for other people. This novel is an illustration of the mad woman in the novel Jane Eyre, by Charlotte Bronte, as the story of her life before madness is told in the novel Wide Sargasso Sea. This study attempts to elucidate reasons for the feelings of displacement that the Western husband faces during his stay in the Caribbean, and also to discover to what extent the situation contribute to the oppression faced by Antoinette and imposed on her by her Western husband. There are many concepts amongst the theory of post-colonialism, e.g. otherness, hybridity, and (double) alienation. This research's approach differs slightly from some previous research that has been done on this novel, as it focuses on the husband of Antoinette as the victim.
\end{abstract}

Keywords: Displacement, postcolonial, Wide Sargasso Sea, Caribbean literature

\section{Introduction}

Coloured people are regarded as 'others', outsiders and of low by some Western people, especially if they are in minority. Although coloured people seem to be displaced when taken to foreign lands and forced into slavery, they end up being the majority and outnumbering the whites who were their colonizers. With this great dichotomy in numbers between whites and blacks, it is apparent that white colonizers will begin to feel alienated and displaced in a foreign land. A feeling of isolation overpowers them when their power as colonizers declines greatly, due to the emancipation of slaves; now being a minority in a foreign land, they will feel both a sense of isolation and a lack of belonging.

There are always two sides to a story, and both sides should be taken into consideration when trying to explain and understand the actions of Western colonizers. Importantly, this paper focuses on a male character of Western origin whose feelings of alienation and displacement shed light on the reasons why he mistreats his wife, Antoinette. Based on the problem as outlined above, the objective of this study is to elucidate the reasons why Antoinette's husband feels displaced in Rhys' novel.

\section{Literature Review}

Wide Sargasso Sea is a famous novel, by Jean Rhys, which justifies the life events of Antoinette who is given a voice to tell her side of the story, a voice she was denied as Bertha in the novel Jane Eyre, by Charlotte Bronte. It is a novel both touching and tragic with characters in conflict, from conflicting backgrounds, who are destined to meet and go through many ordeals caused by family, society and each other. Laura Fish's review of Wide Sargasso Sea by Jean Rhys includes the following: 
Wide Sargasso Sea speaks of the history of cruelty and suffering that lies behind some of the West's accumulated wealth ... This is a book that gives voice to neglected, silenced and unacknowledged stories, exploring different inflections of marginality - gender, class, race and madness. (Fish, 2008)

Wide Sargasso Sea, like most of Jean Rhys's novels, is about a main female character who is ill-treated by her domineering husband. Rhys is known for her themes of oppression and victimization of the female gender. Erika Smilowitz notes that, in each of her novels, Rhys's work involves a repetitive pattern of women being oppressed not only by men but also by society, since 'the men are the society' (Smilowitz, 1986, p. 93).

Smilowitz also quotes from The Fiction of Sex by Rosalind Miles who notes that Rhys's women characters always opposed to "institutionalized masculine hostility in the shape of the law, the professions, the police, the bureaucrats" (Smilowitz, 1986, p. 93). It can be said that Jean Rhys's works are prejudicial to men and somewhat one-sided, as she mainly writes about women's plight. Moreover, Laura Fish also makes an appraisal in her article entitled 'Book of a Lifetime: Wide Sargasso Sea, by Jean Rhys', where she comments:

Wide Sargasso Sea is an inspiration ... Jean Rhys was a post-colonial writer whose work reminds us that "there is always another side, always". (Fish, 2008)

According to Fish, there is always another opinion about a story, the silenced and unfortunate characters have their own past that may have led them to their demise. It is apparent that Jean Rhys views the infamous novel Jane Eyre as one which favoured the 'English side' and thus wrote her own version of events to explain the situation of Mr. Rochester's first wife who was locked up in the attic. This view is supported by Catherine Geenty in her journal article, 'Her skin was darker, her lips thicker than I had thought - An Examination of Blackness in Jean Rhys's Wide Sargasso Sea'.

Most of the research that has been done on Wide Sargasso Sea conspicuously centres on Antoinette, how she is mistreated by her husband and her struggle to be accepted into society. However, this research attempts to focus on Antoinette's unnamed husband and to tell his side of the story. Although it is difficult to shed new light on Wide Sargasso Sea, since so much has already been written about it, my research focuses on the second male narrator instead of the female protagonist.

It can be argued that the unnamed character treats Antoinette badly out of frustration, because of his feelings of alienation and estrangement that render him powerless in a foreign environment. There are scarcely any scholars or critics who have attempted to study this particular character. Mezei's comments pertaining to the second narrator's condition during the second part of the novel support the notion of empowerment by Antoinette:

He loses control of his narration, and Antoinette's thoughts and words invade his mind and his speech. (Mezei, 1987, p. 10)

\section{Postcolonial Theory}

Postcolonial theory is chosen to depict the poignant novel Wide Sargasso Sea by the talented Jean Rhys. Many famous theorists and scholars have contributed to this theory and had their say in their own research on it. Post-colonialism theory has come to be known by several names, e.g. "Commonwealth literature" and "third-world literature", by Marxist critics, as mentioned by Bressler in his work Literary Criticism: An Introduction to Theory and Practice (2011, p. 202).

It is seen as a struggle between continents which comprise the greater and more acknowledged Western authority over the vulnerable continents of Africa and Asia, with the former power's ending as the latter lose the identity they had. In this way, post-colonialism arose after a timespan of some four thousand years of cultural struggle between colonizer and colonized. Charles E. Bressler elaborates further on the birth of post-colonialism theory when he says that the theory evolved from:

...colonized people's frustrations, their direct and personal cultural clashes with the conquering culture, and their fears, hopes and dreams about the future and their own identities. (Bressler, 2011, p. 202)

Bill Ashcroft, Gareth Griffiths and Helen Tiffin are famous theorists who have been deeply involved in this theory, and in their book Key Concepts in Post-Colonial Studies they define post-colonialism thus:

Post-colonialism deals with the effects of colonization on cultures and societies ... the term has been used by literary critics to discuss the various cultural effects of colonization. (Ashcroft, Griffiths \& Tiffin, 1998, p. 185)

What the scholars mean is that post-colonialism is a theory that concerns itself with studying the aftereffects of Western people taking over a certain country to expand their authority over people whom they regard as weak, and the changes that occur to the colony. Additionally, the term of post-colonialism is said to be "a collection of theoretical and critical strategies used to examine the culture of former colonies of the European empires and their relation to the rest of the world" (Makaryk, 1993, p. 155). 
However, Stephen Slemon mentions that the term colonialism arises from a 'problematic category' with its definition being largely debated since it is 'transhistorical and unspecific' and its usage has varied to accommodate numerous types of domination of the historic and economic state of a colony. This is supported by the critic Nicholas Harisson who claims that the theory of post-colonialism "is not an identifiable type of theory in the same sense as deconstruction, Marxism, psychoanalysis or feminism" (2003, p. 203). It can be said that this theory is not the same as others but is rather unique.

Childs and Williams mention the critic Slemon who adds that colonialism persists as an important concept to 'past and present' appraisers in issues regarding the world. Zandra Kambysellis agrees that colonization is an act which conveys:

The suppression, and oftentimes overt annihilation, of the native people's former lives and culture that comes with the new presence of an Other, an Other who believes ... his culture is superior. ( 2 November 2012)

Native peoples had to face colonizers' controlling ways and superiority as they dominated their homeland and told them that their customs were not as great as theirs, thus instilling their culture in the natives by force. It can be said that postcolonialism is a form of struggle that natives have had to endure to adjust to being free from the colonizer and building a new life. It is a difficult task for them to start a new life since they have been accustomed to following the life that they had to adjust to during the reign of Westerners.

Post-colonialism theory has triggered many debates amongst scholars over its definition and functions since it is known for the vastness of the key terms that fall under its scope. These various terms or topics, to name but a few among many, include universality, difference, nationalism, postmodernism as well as feminism, and have been discussed by the three famous theorists of post-colonialism, i.e. Ashcroft, Griffiths and Triffin, in their work. Even though there are many topics that can be found under this heading, Bressler notes that the main concern of post-colonialism is "the struggle that occurs when one culture is dominated by another" (2011).

There are several questions that have been singled out by Peter Childs and R. J. Patrick Williams regarding postcolonial theory when discussing critiques of famous theorists, such as Ashcroft, Bhabha, Spivak and Said. Childs and Williams used 'Wh-' questions, i.e. what, who and when, that relate to post-colonialism. They acknowledge the fact that the term post-colonialism arose after the decline of the authority of the colonizer over the colonies, which the sum up as:

...but that sense of an ending, of the completion of one period of history and the emergence of another, is, as we shall see, hard to maintain in any simple or unproblematic fashion. (Childs \& Williams, 1997, p. 1)

Therefore, when the colonizers had lost their authority, the countries that were under their control began to gain independence and this was questioned by Childs and Williams, who asked: "after whose colonialism" does the period of post-colonialism refer to? They believe that the definition of post-colonialism given by Ashcroft and his team was too broad and not specific enough, and therefore did not really agree with it.

We use the term 'post-colonial', however to cover all the culture affected by the imperial process from the moment of colonization to the present day. (Ashcroft, 1998, p. 3)

It can be seen that the definition by Ashcroft is quite general as there are many forces that are associated with the colonizing party and the colonized victims. From the questions that arose and were confronted by both Childs and Williams in their research, they came up with a conclusion to the effect that:

We do think that post-colonialism as an historical period is best understood as a phase of imperialism, in turn best understood as the globalizing of capitalism, but that it is not simply or everywhere reducible to these categories. (Childs \& Williams, 1997, p. 21)

What they are trying to voice is that the term post-colonialism theory is not able to "master and explain" every single detail regarding the issues of post-colonialism, and therefore theorists should "try to understand or explain as much of what is going on as possible" while omitting as little information as possible.

The theory has also been used in literary works where its main focus is to highlight events that occurred during the time of pre-colonization and also post-colonization. John Lye points out that postcolonial theory is used during the process of writing literary works about colonized people, either by the colonized people or the colonizers themselves. In his journal article, Lye gives his opinion about the theory and mentions that postcolonial:

...deals with the reading and writing of literature written in previously or currently colonized countries, or literature written in colonizing countries which deals with colonization or colonized peoples. (Lye, 1998) 
Lye also states that this particular "reading and writing of literature" is centred around two factors. Firstly, in what manner does literary work by the "colonizing culture" alter the "experience and realities" whereby they make colonized native people feel that they are mediocre. The second factor is the fact that colonized native people wrote literature in an effort to claim their rights during the time of colonization.

Furthermore, the colonized people are not the only ones who discover their newfound freedom through writing about their experiences of being colonized and their life after gaining independence, the colonizers also contributed to writing the literature of post-colonialism.

British heritage moved in to new landscapes, established new founding national myths and struggled to define [its] own national literature against the force of ... British tradition ... [it] encountered the originating traditions as Other, a tradition of writing to define oneself against. (Lye, 1998)

From the statement above by John Lye, it can be said that Western colonizers were also having difficulty in trying to establish themselves in a foreign environment where there already existed traditions and culture. To try to dominate over colonized cultures and form a new one is a difficult task, and therefore they wrote works of literature with their home country as the audience in order to define themselves as the great dominators.

\section{Displacement}

For this paper, the concept of displacement which falls under postcolonial theory is used. The concept of displacement is defined by The Little Oxford Dictionary simply as:

Displaced person - one who has had to leave his home country as result of war, etc. (2008, p. 157)

It also denotes the fact that a person is forced to move from the comfort of their familiar surroundings to a wholly new place which is unfamiliar and strange to them. In these new surroundings, a person will have difficulty assimilating into the new culture and, slowly, a sense of seclusion will start to emerge. When one experiences a lack of belonging to a place in which one is currently residing, it will be difficult to adapt to the new environment. This will lead to loneliness and paranoia.

The experience of displacement can be seen in the life of the post-colonialism author V.S. Naipul, who was born in West Indian Trinidad but lived most of his life in England. The sense of displacement that he experienced was proven when Naipul stated, "When I speak about being an exile or refugee, I am not just using a metaphor, I am speaking literally" (Evans, 62). Naipul's statement denotes that although he had lived in England for many years, a sense of belonging eluded him. The experience that V.S. Naipul states is comparable to that experienced by Antoinette's husband in the novel Wide Sargasso Sea.

In the novel, the main characters experience displacement and are deeply affected by it, such that it influences their behaviour and daily life. For Antoinette, although she was born and raised in the Caribbean, she never felt like she belonged as she was creole; and as for her husband, he felt displaced as he had travelled hundreds of miles from the comforts of his home country to a foreign one which was a strange new world to him, with neither relatives nor close friends. Antoinette's husband had no one that he could relate to regarding his emotions, and as a person deemed a powerful Western man, he had to keep his emotions in check and not reveal them to the public gaze.

This concept has constantly been associated with colonized populaces, in the same sense ignoring the fact that colonizers can also experience a sense of displacement. Leorna Farber, in her journal 'Dis-location, Re-location: Colonial \& Postcolonial Narratives of White Displacement in South Africa', mentions two critics, Melissa Steyn and Gerald l'Ange, who have had their say on the matter of the decolonization period, noting that the colonizers felt disconnected from their 'European roots' during this period (2009, p. 7). From this it seems the European colonizers felt displaced when they were in a foreign land, and especially when their sense of superiority was decreasing.

\section{Lack of Belongingness: Displacement}

But the feeling of something unknown and hostile was very strong. 'I feel very much a stranger here,' I said. 'I feel that this place is my enemy and on your side. (Rhys, 2001, p. 82)

In her novel Wide Sargasso Sea, Jean Rhys presents the idea of a lack of belonging in the character of Antoinette; although she was born and raised in the Caribbean, she never felt like she belonged there. This was due to the fact that she grew up in a society that treated her poorly, and this drove her to become a loner. The researcher is of the opinion that Rhys focuses on the mistreatment of her main character, Antoinette, because she favours her and sympathizes with her, thus neglecting Antoinette's husband.

This section aims to highlight the second narrator's feeling of not belonging and his situation will be further explained with evidence presented throughout this paper. Antoinette's husband felt like a stranger in his wife's country and threatened in a foreign land. This can be seen in the aforesaid dialogue, taken from Rhys's novel, which displays evidence of his feelings of discomfort. A person experiencing a sense of not belonging characterizes the concept of displacement, which comes under the theory of post-colonialism. 
The concept of displacement was formed in order to describe the results of activities involving countries which, in pursuit of political authority, colonized and terrorized third-world countries for their own benefit. As Rajeswari Sunder Rajan notes, talking about:

...the large-scale displacement and dispersal of populations across the world as a result of major political upheavals, among them the European wars, decolonization and the Cold War. (Rajan, 1)

It can be said that people were deeply affected by colonization and had started to feel alienated in their own country, because of the emerging cultures and lifestyles of their colonizers, which threatened to oust theirs. However, it can also be said that the colonizers also felt displaced in the colonies that seemed completely foreign to them, and no matter how long they lived there, the feeling of displacement would linger on.

Natalie Edwards and Chistopher Hogart, in their edited version of Gender and Displacement: "Home" in Contemporary Francophone Women's Autobiography, are of the view that the definition of the concept of displacement supports the above statement, which alludes to the weakening progressive sense of belonging of a person in a specific habitation $(2008$, p. 2). This shows how displacement affects people, especially Antoinette and her husband in Wide Sargasso Sea. A displaced person will feel disconcerted and the feeling of attachment to a certain place they were once familiar with will be unfamiliar to them.

Everything is too much ... Too much blue, too much purple, too much green ... Dear Father ... I will never be a disgrace to you or to my dear brother the son you love. No begging letters, no mean requests. (Rhys, 2001, p. 39)

Family obligations can compel a person to make certain life-changing decisions, just as the second narrator of Wide Sargasso Sea did. Leaving the comforts of home and the familiarity of a routine daily life often leads to a feeling of displacement, and in the case of the second narrator, he had to travel abroad, to the Caribbean. His decision hinged on his yearning for his father's love and respect, as well as his dignity, and to prove that he was a man capable of doing well on his own.

Angela Gussing opines that people who decide to travel far from their homeland often consider their actions to be a 'temporary measure', without thinking deeply about the consequences and with a belief that they will return to their homeland almost immediately. It can be said that the second narrator thought that his journey to the Caribbean would be transitory, and throughout the novel the reader can discern his wistful thinking of England and his feelings of anxiety and not belonging while residing in his wife's country. Furthermore, Gussing adds the following fact about establishing belonging:

They are likely to seek shelter among family/friends in nearby communities so as to minimize the disruption to their normal lives. (14 April 2013)

Gussing's theory cannot, however, be applied to the second narrator because he did not have any relatives or friends in the Caribbean, hence his normal life was disrupted. As noted by Karolina Tennholt in 'Patriarchal madness - Patriarchal oppression and madness in Jean Rhys's Wide Sargasso Sea', the act of establishing the feeling of belonging to a certain place, especially a 'second home', is a difficult task and this was the situation faced by the second narrator (2005, p. 16).

His circumstances would have led him to feel displaced and thus affect his behaviour towards the people around him. This negative behaviour is witnessed when the second narrator changes his wife's name from a French name, Antoinette, to an English one, Bertha, in order to feel more in tune with his British roots. This was thus the subtle beginning of female oppression.

'Don't laugh like that, Bertha.' 'My name is not Bertha; why do you call me Bertha?' 'Because it is a name I'm particularly fond of. I think of you as Bertha.' (Rhys, 2001, p. 86)

The excerpt shows the second narrator's wish to connect to England. He wants a British wife who belongs to him. According to Vilja, the behaviour that he portrays is an attempt to attain "some sensation of power", since he could not annul his marriage. He felt scared and uneasy, not only that Antoinette belonged to her natural surroundings, but that they complemented her. This is clearly shown by Rhys on page 112, where we see the feelings of the husband about Antoinette and nature:

I hated the sunsets of whatever colour, I hated its beauty and its magic and the secret I would never know ... Above all I hated her. For she belonged to the magic and the loveliness. (Rhys, 2001, p. 112)

His feelings of resentment towards the environment and especially towards his wife caused him to mistreat her. However, Theresa F. O'Connor argues that his cruelty resulted from the bitterness he harboured at being rejected by the person he looked up to, his father (1986, p. 162). He vents his anger and frustrations on his wife, Antoinette, since he could not do so on his own father. 
The second narrator's feeling of displacement could have been triggered by his weak sense of security. His current dwelling was undeniably different from his homeland, and this led to feelings of hostility towards everyone and everything around him.

...but it seemed to me that everything round me was hostile. The telescope drew away and said don't touch me. The trees were threatening and the shadows of the trees moving slowly over the floor menaced me. That green menace. (Rhys, 2001, p. 96)

Antoinette's husband's insecurity and feeling of abandonment led him to experience paranoia. He felt worried for his own safety when continuing to live in the Caribbean. He felt an animosity towards everything around him and his power as a white colonizer was negated since Emancipation had stripped the whites of their authority and rights over the natives and the environment.

It cannot be denied that one's defences may be weak at certain points in life. Antoinette's husband had started to express feelings of seclusion and lack of belonging when he was in the Caribbean. He could not call his wife's home his own because he felt no comfort there. Antoinette had tried to make him feel at ease in Granbois, the place she grew up in, and her love for the place was evident when she talked of her childhood there. However, it was clear that her efforts were unsuccessful, as shown in the second narrator's thoughts below:

I had felt it ever since I saw this place. There was nothing I knew, nothing to comfort me. (Rhys, 2001, p. 96)

Furthermore, the environment around him was not the same as the environment that he was accustomed to in his motherland, England. He also did not feel the same comfort that Antoinette felt, no matter how hard he tried. Apart from family obligations, the practice of favouritism by the second narrator's family in England had forced him to relocate to the Caribbean. It was said that he was the least favourite son of his father and that he could never compete with his elder brother to win their father's affections. This is evident from the letter that he wrote to his father in England:

Dear Father ... I will never be a disgrace to you or to my dear brother, the son you love. No begging letters, no mean requests. None of the furtive shabby manoeuvres of a younger son. (Rhys, 2001, p. 39)

Men are known for being patriarchal and taking control of their lives. In the case of Antoinette's husband, he believed that his authority had been challenged: he had grown up thinking that he was not as good as his brother, the favoured son. He went to great lengths to gain his father's approval and respect, to the extent of moving away from the comforts of life in England to seek his fortune on foreign shores.

This leads to the concept of displacement, a word which denotes ambiguity, which applies to the second narrator. Firstly, displacement denotes a feeling of a lack of belonging, which the second narrator feels when he is around his family in England and also during his stay in Antoinette's homeland. Secondly, displacement indicates an act of relocating, which Antoinette's husband endured when he moved from England to the Caribbean.

"The thirty thousand pounds have been paid to me without question or condition." (Rhys, 2001, p. 39)

Besides having to relocate to another country, Antoinette's husband was also having trouble establishing himself to his family as a capable man. This can be seen in the above excerpt from the novel regarding his current financial status. Since his relationship with his father and brother was not close, it was apparent that his brother would receive the family inheritance, thereby leaving him with no capital of his own. These were the reasons that compelled him to follow his father's orders to go abroad and marry an heiress whose background he was not aware of, just so that he could make an impression on his family, especially his father. This fact is endorsed by the following excerpt, taken from a letter addressed to his father:

"I have a modest competence now ... I have sold my soul or you have sold it, and after all is it such a bad bargain?" (Rhys, 2001, p. 39)

One can also sense the resentment and bitterness felt by the second narrator. He feels like a puppet being manipulated by his father for financial gain. In many of the studies done on Wide Sargasso Sea, the second narrator is portrayed as a character who tricked Antoinette into marrying him, a man hungry for wealth and power. Vilja Hogstrom states, in her article entitled 'Antoinette - A Hybrid Without a Home Hybridity in Jean Rhys's Wide Sargasso Sea', the following:

...as her father-in-law presents her to a man interested in marrying her, for money. Antoinette is more or less sold into a marriage none of them had planned or desired earlier. (Hogstrom, 2009, p. 15)

The researcher agrees with Hogstrom's comments pertaining to the unplanned marriage of both characters, as they were not brought together of their own volition. However, the researcher does not entirely agree with Hogstrom's statement about Antoinette being the sole victim of manipulation as the second narrator was also victimized. 
If not for his father, the second narrator would not have had to cross an ocean to marry a woman he had never met nor live in a place he was unfamiliar with. While it can be said that he sold his dignity because he was unable to decide on the course of his life, it is evident that his father played a pivotal role in planning his future. The feeling of nonbelonging had been sown on its own and deepened throughout his stay on the island.

When one is displaced, one tends to yearn for the comforts of a familiar place one calls home. One is overcome by feelings of wistfulness, which eventually lead to an attitude of indifference and fault-finding. Some of the conversations between Antoinette and her husband revolve around comparisons of their native countries.

The earth is red here, do you notice? It's red in parts of England too. (Rhys, 2001, p. 40)

However, Antoinette's husband always chose to portray his home country, England, as perfect and civilized, but not Antoinette's homeland. A conversation between husband and wife on page 47 of Wide Sargasso Sea displays the former's apparent competitiveness in this regard when Antoinette questions him about England.

...London is like a cold dark dream..." " ...your beautiful island seems to me ... like a dream." "But how can rivers and mountains and the sea be unreal?" "And how can millions of people, their houses and their streets be unreal? (Rhys, 2001, p. 47)

Both characters feel that their partner's respective country is dreamlike. He becomes irritated when Antoinette says that England is like an imaginary country for her. In his opinion, the setting of his wife's home feels dreamlike and unreal. The setting he was used to was of brick buildings and cold weather, which is real and totally opposite to the exotic island he is currently residing on.

This leaves him wistful and frequently thinking of England during his stay on the island. Clearly, he longed to experience something familiar from his culture, and more so whenever he discovered something from his wife's culture. This feeling of not belonging deepens with each difference and unfamiliarity that he encounters.

After breakfast at noon there'd be silence till the evening meal which was served much later than in England. (Rhys, 2001, p. 54)

\section{Conclusion}

In this research, the researcher has examined the life of the character of Antoinette's husband in the novel Wide Sargasso Sea, written by the Dominican author Jean Rhys. Countless studies have been done on the novel and a certain pattern can be seen in the approach that researchers have used to study this novel, and this involves taking the side of 'the other' in the novel. 'The other' that is mentioned is the black people in society, and it is especially the creole woman called Antoinette who has been paid much attention as the main subject matter in other research.

The stereotyping of people based on their skin colour is an act not recommended to be imitated; but in reality, it is one of the main problems currently happening in the world today. People with white or fair skin are regarded as people with a good upbringing, cultured and superior, while people who have black or coloured skin are regarded as senseless, uncivilised and inferior when compared to 'whites'. From this viewpoint, this labelling of people according to their skin colour is unfair and, moreover, people are not what they seem to be according to their appearance.

People are to some extent unaware of the fact that the 'whites' whom they think of as superior colonizers may also have their flaws. They are not always as controlled and dignified as people seem to think they are, and they may also have a moment of weakness when they face a situation that drains them of their confidence.

Given the aforementioned factors, it can be concluded that Antoinette's husband did not cross an ocean to an unknown world simply to amuse himself. Undoubtedly, his actions were involuntary and a consequence of his father's planning. The feeling of ostracism intensified in the moment when he realized how great was the difference between his wife's world and his own. It can therefore be concluded that the feelings of displacement experienced by people often lead to a feeling of alienation.

\section{References}

Ashcroft, B., Griffiths, G., \& Tiffin, H. (2002). The empire writes back (1st ed.). London: Routledge.

Bressler, C. (2011). Literary criticism (1st ed.). Boston: Pearson Longman.

Childs, P., \& Williams, P. (1997). An introduction to post-colonial theory (1st ed.). London: Prentice Hall/Harvester Wheatsheaf.

Edwards, N., \& Hogarth, C. (2008). Gender and displacement (1st ed.). Newcastle upon Tyne: Cambridge Scholars Pub.

Farber, L. (2009). Dis-location/re-location: colonial and postcolonial narratives of white displacement in South Africa. University Of Art And Design, Helsinki.

Fish, L. (2008). Book Of A Lifetime: Wide Sargasso Sea, by Jean Rhys. The Independent. Retrieved from http://www.independent.co.uk/arts-entertainment/books/reviews/book-of-a-lifetime-wide-sargasso-sea-by-jean-rhys876227.html 
Hogstrom, V. (2009). Antoinette-A Hybrid Without a Home: Hybridity in Jean Rhys's Wide Sargasso Sea.

Harrison, N. (2003). Postcolonial criticism (1st ed.). Cambridge, UK: Polity Press in association with Blackwell Publishers.

Livingstone, C. (2008). Little Oxford dictionary and thesaurus (1st ed.). Oxford: Oxford University Press.

Lye, J. (2014). Some Issues in Postcolonial Theory. Brocku.ca. Retrieved 7 July 2014, from http://www.brocku.ca/english/courses/4F70/postcol.php

Makaryk, I. (1993). Encyclopedia of contemporary literary theory (1st ed.). Toronto, Ont.: University of Toronto Press.

Mezei, K. (1987). “And it Kept its Secret”: Narration, Memory, and Madness in Jean Rhys' Wide Sargasso Sea. Critique: Studies In Contemporary Fiction, 28(4), 195--209.

O'Connor, T. (1986). Jean Rhys (1st ed.). New York: New York University Press.

Rajan, R. (n.d.). Concepts in Postcolonial Theory: Diaspora, Exile, Migration, 1.

Slemon, S. (1997). Unsettling the Empire: Resistance Theory for the Second World Stephen Slemon. New Contexts Of Canadian Criticism, 228.

Smilowitz, E. (1984). Childlike Women and Paternal Men: Colonialism in Jean Rhys's Fiction.ARIEL: A Review Of International English Literature, 17(4).

Tennholt, K. (2005). Patriarchal madness -Patriarchal oppression and madness in Jean Rhys's Wide Sargasso Sea. Södertörn University College. 